International Journal of English Literature and Social Sciences
Vol-6, Issue-4; Jul-Aug, 2021

Peer-Reviewed Journal

\title{
Strained Family Relationships and Botched Careers in Jonathan Franzen's Novels - Corrections and Purity
}

\author{
Mrs. Jyothi Katari ${ }^{1}$, Professor P. Rajendra Karmarkar ${ }^{2}$
}

${ }^{1} \mathrm{PhD}$ Scholar, Andhra University, Visakhapatnam, Andhra Pradesh, India

${ }^{2}$ Principal, College of Arts and Commerce, Andhra University, Visakhapatnam, Andhra Pradesh, India

Received: 12 Jun 2021; Received in revised form: 14 Jul 2021; Accepted: 20 Jul 2021; Available online: 27 Jul 2021

(C)2021 The Author(s). Published by Infogain Publication. This is an open access article under the CC BY license

(https://creativecommons.org/licenses/by/4.0/).

\begin{abstract}
A National Book Award writer Jonathan Franzen received extensive critical praise for the novel The Corrections focuses much on family members whose marriages are unsuccessful, strained familial relationships, and failed careers. In 2001 the novel 'the corrections' was at the centre of a dispute between American television talk-show hosts Oprah Winfrey, who selected it for her extensively popular book club. Franzen's engrossment with family influences was visible in his later novel, Purity which describes a young woman whose mother always refuses to reveal her origins. Finally she joins an organization resembling Wiki leaks and becomes involved with its terrific leader. Franzen showed the troubles of Pip and how it takes away to understand the world and which is predictably extensive cast of supporting characters, to meet a sharp critique of consumerism, digital culture, and human solipsism.
\end{abstract}

Keywords-Corrections and Purity, Time Magazine, Jonathan Franzen

\section{INTRODUCTION}

On the Cover of Time Magazine from head to foot the big headline about Jonathan Franzen is a "Great American Novelist'" appeared in 2010. Jonathan Earl Franzen born on August 17th 1959 is an American Novelist and Essayist, his initiation of writing as a novelist started with Twenty seventh City, his debut novel published in 1988. The novel is a kind of complex partly satirical thriller and it studies family pressures, political and economical disturbances in St.Louis Missouri, in the year 1984. His second novel in 1992 Strong Motion is passionate on social criticism, and speaks about different themes like abortion feminism, exploitative capitalism etc. In 2001, his third novel The Corrections was a big hit and received a National Book Award and Pulitzer Prize for Fiction Finalist, earned a James Tait Black Memorial Prize and was selected for International Dublin Literary Award. The novel rotates the troubles of an elderly Midwestern couple and their three grown up children tracking their lives from the mid 20th century. His fourth novel Freedom was published in 2010 by Farrar, Straus and Giroux. Freedom received general acclaim from book critics, and was rated one of the best books of 2010 by various publications. His fifth novel Purity was published on 1st September 2015 by Farrar, Straus and Giroux. It is composed of six sections that focus on several different characters, diverging ages and backgrounds. Franzen's very recent novel Crossroads will employ Franzen's signature multiple-narrator style to crack open the hearts of the family at the main theme of the story - the same characters who will form the backdrop of the entire trilogy.

In the 21 st century in recent years, Franzen has come up with his opinions on how people and everything from social networking services such as Twitter, WhatsApp, Facebook etc...What happens to the people and why these electronic distractions, they are able to communicate face to face, individual to individual, more usage of e-books. All the real things turned as the authentic things, while the honest things were dying off. Franzen spoke much about family issues, realism, fame, political and economical issues, feminism, and the self-destruction of America. The irony is in Franzen's novel to upgrade the connection of 
bodies over the connections made through computers. Facebook, Twitter and virtual realities move his characters feeling isolated. It is the intersections of bodies and collisions of physical desire where characters find connections and redemption. While postmodernism was gradually grown in the 1990s, a new generation of playwrights have come of age; a generation that undertakes to move beyond the extensive irony and selfreflection of postmodernism. This movement, which in addition to Franzen assimilates figures such as David Foster Wallace, Richard Powers, William Vollmann, Dave Eggers, Nicole Krauss and Jonathan Safran Foer, is temporarily labeled post-postmodernism by Burn. Franzen used the post-postmodernism concept in his writings like freedom and other writings.

The major conflicts in the novel The Corrections are the conflicting desires and ideals of each member of Lambert family. They struggle to find happiness for themselves, without neglecting their familial duties. The title The Corrections indicates one of the main ideas inside. Most of the characters in this novel are trying to correct their lives, and they always get out of the failures they have been living in. However, it is proved that The Corrections of the title is abruptly suitable for the novel, because it actually shows how people are correcting their mistakes without hiding them. The 21st century modern American social criticism has been acclaimed 'the Bleak House of the digital age' and 'hysterical realism', a subgenre of postmodern fiction, defined by chronic length, frenzied action. The novel explores the dark corners of multiple areas, whereas economical colonization, pharmaceutical industry and globalization to the state of central Europe, but it's appealing and bringing kindness and humanity to its epic tale of the dysfunctional Lambert family and their attempt to meet for one last family Christmas.

In the story of The Corrections, Alfred and Enid Lambert and their three adult children, Gary, Chip and Denise, bear a heavy burden. Gary is steering the straits of depression while trying to secure a happy family life; Chip is satisfying his university time with his attraction towards young girls and the inevitable consequences; and Denise is balancing her success as a chef with her uncontrolled sexual tastes and her mother's wish for her to settle down and marry. Enid is bearing all these difficulties apart for all these Alfred has Parkinson disease, neurological disorder. With Alfred's Parkinson disease worsening, his family must cope with his firm insistence to refuse extra care.

Gary strives hard to get more money from his patent with his father's insistence. Gary has known that he has to care for his parents with force when they run out of money. He finds difficulty to handle both mother and his wife. He is caught in the middle of their argument about Christmas. This novel displays family as being a burden, but also something to live for, as both Gary and Carolinec recognize that Gary parents have almost nothing in their lives.

Chip Lambert is the protagonist character in the novel The Corrections who is bitter about his life. He considers himself to be an intellectual. He was a tall, gym-built man with crow's-feet and sparse butter yellow-hair. His wardrobe consists of mainly leather. He wears an old quarter-inch rivet as an earring, and he has minor obsession with sex. He was suspended from a teaching job at a university because he had an affair with a girl who is studying undergraduate, and then he started using his own skills of writing. While attempting to finish and sell a screenplay, he does unpaid work for the Warren Street Journal, and is a full time legal proofreader. Denise is another interesting character in this novel; she is a sister of Chip, who is a beautiful and efficient chef at a restaurant in Philadelphia. She bailed Chip out after being laid off from his job as a professor by giving him money, but later she refuses to help him any longer.

It is funny and a little ironic that it is a seventy five year old mother Enid Lambert who appears as the heroine in the end. She is a hoarder and has a damaged hip. She is terribly anxious. But she would never reveal about her husband Alfred who lost his faith in reality with her neighbors or her three grown children. It may due to the medication that Alfred takes for his Parkinson's disease, or maybe it is his negative attitude, he spends his days gloomy in the basement and commits shadowy, dark and unspeakable acts. More and more often, he doesn't seem to understand a word Enid says. Enid Lambert always tries to manage things. She comes across as fairly obtuse, and often says tactless things to her son and husband. Her obsession with material objects manifests itself not just in her hoarding, but in her constant badgering about a very wealthy acquaintance.

Trouble started in the lives of Enid and Alfred's children. Their first son, Gary, who is working as a banker in Philadelphia, has convinced his parents harshly and is trying to force them out of their old house and into a small apartment. The second child, Chip, has suddenly quit a job as a professor at D------ College due to his affair with an undergraduate girl and moved to New York City, where he seems to be pursuing a "transgressive" lifestyle and practicing writing some sort of screenplays and becoming a permanent proof reader. Meanwhile the girl child of the family, Denise, spoils her marriage only to drain her 
youth and beauty down the drain of an affair with a married man.

The significance of the novel genre for Franzen lies not with the stories it can describe but with the fact that it can narrate any story at all, that the novel as a form enables the making visible of that stream of connections and unities that establish a life, whereas life itself, beaten with distractions and weak with forgetting, hides nine-tenths or more of the work that creates and sustains it. The Corrections asks as much of its readers as it questions of itself, and the determination that drives it to melt down and merge the interlocking relations, careers, and madness's of a Midwestern, middle-class, middle-aged American family is an ambition its readers must take on themselves if they are to make it through pages that simultaneously have the analytical idea of their own families and situations..

Another interesting novel by Jonathan Franzen Purity is about typical and complicated families, and people captured by the practices they create their own fame, socialism, moral hegemony, marriage, guilt, and the internet. In this novel, with its nod to Great Expectations [1], Franzen addresses the corrupting power of fame and money and the inheritance of a broken world. Franzen initiates the novel Purity Annabel's eyelid twitching or the lady thinks it is, so she says her excited daughter, Pip Tyler, who is working as an outreach specialist for an energy company.

The full name of the girl Pip is called Purity; she is the only child of a secluded woman. She is a graduated young girl; her mother always refuses to tell the truth of her father and her real birthday also. Pip is $\$ 130,000$ in debt for her college fee, living in a house with dissatisfied Occupy protesters, and working at a call center. Her desperation propels her into an internship in Bolivia with the Sunlight Project of wiki leaks organization, her journey started with her new employer Andreas, who is unfortunate man with a murder on his troubled relationship with his mother. Andreas knows that Tom Aberant is the father of Pip so Andreas sent Pip to Denver to work as an intern scholar in Tom's newspaper; if she finds her father she can reestablish their relationship. Another scene starts with a new relationship in this novel with Jason, Andrea's commits suicide. These situations deal with search for one's identity, psychological distress and typical relationships. The novel describes new narrative style, presence of technology, transparency, which was never mentioned in previous fiction.

Purity shows a search for identity driven by a void in Pip's knowledge regarding her father - "we enter existence bodily, by way of a mother and a father who are not-us but whose lives impinge on ours from cradle to grave" (Weinstein 203-4). Hence, the characterization Franzen develops in his last two novels can be distinguished first and foremost by the kind of search presented. Once she has found her father's and mother's true identities, Pip feels she has reached her aim and "has gained access to her true self" (Hidalgo, Jonathan Franzen 227).

One of the interviewed Jeremy Potier asked Jonathan Franzen, Franzen had a special interest in what the form of family allows for in terms of narrative strategies and arguably a way of bringing together independent yet interconnected stories. Franzen replied with lots of enthusiasm and interest he has taken real example of his own dentist in New York who has three brothers, all of them FBI agents. It is an unusual thing, in that most of the families' children are different from their siblings, novelists require these kinds of situations. And he said

"If you're painting on a fairly large canvas, it gives you different colors and flavors to work with. It allows me to be a social novelist, in a sense, but not a didactic social novelist, not an instructive social novelist. I'm not serving social reality; I am making its particulars serve me.' "Family is a signification-rich structure! The writer can tap into universal conflicts just by writing the words "son" and "father." ---Jonathan Franzen

Jonathan Franzen replied in the same interview that he was not a family novelist. In The Corrections, it's kind of Family novel he describes the only family we really see interacting is Gary's. All of the five members of Lamberts are living together in the same place in the end of the novel. Franzen told that a family of five original characters is in relation to each other and they have feelings about each other, but we see almost nothing of their actual family life. He made five independent characters organized conveniently. In a family, everyone has strong feelings about each other. 'Family is a signification-rich structure! The writer can tap into universal conflicts just by writing the words "son" and "father."-Jonathan Franzen.

\section{REFERENCES}

[1] Great Expectations was written by Charles Dickens in 1860 and 1861.The mid-19th century was a time of great social change in Britain. There was increasing movement from the countryside to the towns, education was slowly improving and the legal system was being changed. The novel reflects such changes.

[2] Carola Campbell--along with Gabrielle Mander--is a contributor to the "Modern Fiction" section of 501 MustRead Books (2014),

[3] Adams, Tim. "Purity by Jonathan Franzen review piercingly brilliant." 06/09/2015. The guardian. Accessed 
$12 / 02 / 2019$.

<https://www.theguardian.com/books/2015/sep/06/purityjonathan-franzenreview-piercingly-brilliant $>$.

[4] "Jonathan Franzen, The Art of Fiction No. 207." The Paris Review

https://www.theparisreview.org/interviews/6054/jonathanfranzen-the-art-offiction-no-207-jonathan-franzen.

[5] Franzen, Jonathan (8 June 2015). "The Republic of Bad Taste". The New Yorker. Retrieved 20 August 2015.

[6] "National Book Awards - 2001". National Book Foundation. Retrieved 2012-03-27.

[7] "Purity: A Novel - Jonathan Franzen; Read by Dylan Baker, Jenna Lamia, and Robert Petkoff". Macmillan Publishers. Retrieved October 10, 2019.

[8] https://www.gradesaver.com/the-corrections/studyguide/character-list

[9] https://www.britannica.com/topic/The-Corrections

[10] https://www.shmoop.com/study-guides/literature/thecorrections/enid-lambert

[11] http://www.bookrags.com/studyguidepurity/chapanal001.html\#gsc.tab $=0$

[12] https://journals.openedition.org/transatlantica/8943

[13] https://politicsandculture.org > 2010/12/30 > jonathan-fra. 